\title{
HUBUNGAN KOMUNIKASI DENGAN DISIPLIN KERJA KARYAWAN CHANDRA DEPARTEMEN STORE TANJUNG KARANG DI BANDAR LAMPUNG
}

\author{
Nur'aeni ${ }^{(1)}$, Sela Efiani ${ }^{(2)}$ \\ Fakultas Ekonomi Universitas Sang Bumi Ruwa Jurai \\ nuraeni@fe.saburai.ac.id, sela.efiani43@gmail.com
}

\begin{abstract}
Abstrak. Chandra Departement store Tanjung Karang adalah salah satu perusahaan yang bergerak di bidang retail di Bandarlampung dan merupakan cabang Chandra Superstore yang ketiga. Semakin banyaknya pesaing di bidang yang sama membuat manajemen Chandra Departement store Tanjung Karang untuk meningkatkan kualitasnya. Penelitian ini bertujuan untuk mengetahui hubungan komunikasi degan displin kerja karyawan pada Chandra Departement store Cabang Tanjung Karang. Pengambilan Sampel dilakukan dengan non probability sampling dengan teknik purposive sampling dan setelah dilakukan perhitungan diperoleh sebanyak 86 responden. Berdasarkan hasil pembahasan yang dilakukan diketahui bahwa nilai koefisien korelasi product moment sebesar 0,812 dengan nilai $\mathrm{N}=86$, berarti bahwa terdapat hubungan yang kuat antara komunikasi dengan diplin kerja karyawan. Sedangkan pengujian hipotesis menggunakan uji-t di dapat bahwa nilai $t_{\text {hitung }}(12,751)>t_{\text {tabel }}(1,989)$, maka Ho ditolak dan Ha diterima yang berarti secara keseluruhan variabel bebas (komunikasi) mempunyai hubungan yang positif dengan variabel (disiplin kerja).
\end{abstract}

Kata kunci: Disiplin, Hubungan, Karyawan, Kualitas.

\section{PENDAHULUAN}

Tujuan dasar dari setiap perusahaan adalah untuk memperoleh keuntungan yang maksimal serta meningkatkan kesejahteraan karyawannya. Untuk mencapai tujuan tersebut dibutuhkan karyawan yang berkompeten, memiliki kinerja serta disiplin kerja yang tinggi agar dapat memberikan kontribusi bagi perusahaan dalam mencapai tujuan. Dalam hal ini peran seorang pemimpin perusahaan sebagai pembuat dan pengambil keputusan sangat penting untuk dapat memberikan perhatian dan penghargaan kepada setiap bawahannya, sehingga mereka dapat mengetahui tugas dan kewajibannya serta paham atas kebijakan dan tujuan perusahaan.

Keberhasilan suatu perusahaan tergantung pada sumber daya manusia yang dimilikinya, besarnya kontribusi sumber daya manusia dirasakan jauh melampaui peran yang diberikan sumber-sumber lain, seperti faktor modal, manajemen, alat-alat produksi dan bahan baku. Pendayagunaan sumber daya manusia yang tepat dalam mengelola suatu organisasi atau perusahaan menjadi penentu kelangsungan hidup perusahaan, sehingga pengelolaannya harus dilaksanakan dengan sebaik mungkin agar perusahaan memperoleh manfaat yang optimal. Pengelolaan yang tepat dari faktor manusia adalah dengan menerapkan prinsip-prinsip manajemen personalia.

Tujuan dari manajemen personalia merupakan tujuan dari perusahaan untuk mendayagunakan tenaga kerja dan kerja sama dalam perusahaan guna mendapatkan keefisienan dan keefektifan dalam bekerja sehingga mendapatkan output yang optimal dengan sedikit tenaga kerja. Pemberdayaan tenaga kerja secara optimal salah satunya dilakukan dengan cara menciptakan hubungan komunikasi yang baik antara pimpinan dan karyawan. Setiap perusahaan pasti menginginkan setiap karyawannya, memiliki disiplin yang tinggi, karena 
dengan diplin yang tinggi dari masingmasing karyawan maka tujuan perusahaan akan lebih mudah tercapai.

Faktor penting dalam organisasi adalah komunikasi. Komunikasi merupakan alat penting guna menciptakan kerjasama di dalam suatu organisasi dalam mencapai tujuannya. Komunikasi akan memungkinkan setiap anggota organisasi untuk saling membantu, memberikan informasi, mengadakan interaksi dan saling mempengaruhi sehingga kesetabilan organisasi akan dapat dipertahankan keberadaaannya.

Latar belakang terjadinya komunikasi adalah untuk menghindari terjadinya konflik yang disebabkan oleh kesalahpahaman komunikasi ( misscommunication) didalam perusahaan. Dalam hal ini komunikasi merupakan proses pemindahan pengertian dalam bentuk gagasan atau informasi dari seseorang ke orang lain. Perpindahan ini melibatkan lebih dari sekedar kata-kata yang digunakan dalam percakapan, tetapi juga ekspresi wajah, intonasi, titk putus vocal dan sebagainya. Pelaksanaan komunikasi yang tidak baik dalam suatu organisasi akan mengakibatkan semua rencana, instruksi, petunjuk, saran, motivasi dan sebagainya akan menemui gangguan yang akhirnya akan mengakibatkan pekerjaan menjadi simpang siur sehingga akan menghambat pencapaian tujuan organisasi.

Tujuan perusahaan dengan hasil yang maksimum akan semakin mudah tercapai tidak hanya dengan pengelolaan komunikasi yang, tetapi juga dengan adanya disiplin kerja yang tinggi dari seluruh karyawan. Salah satu cara yang harus dilakukan untuk mencapai disiplin kerja karyawan yang tinggi adalah dengan menggunakan komunikasi yang efektif. Komunikasi merupakan proses penyampaian informasi, perintah, pesan atau ide dari seseorang kepada orang lain shingga terjadi interaksi diantara mereka. Untuk itu dibituhkan pengelolaan komunikasi yang baik dapat memberikan nilai tambah bagi perusahaan di dalam persaingan dunia usaha.

Chandra Departement Store Tanjung Karang yang berdiri sejak Tahun 1998 merupakan salah satu perusahaan yang bergerak pada bidang retail di Provinsi Lampung. Chandra Departement Store yang berlokasi di Jalan Pemuda-Hayam Wuruk No.1 Tanjung Karang merupakan cabang Chandra Departement Store yang ketiga. Chandra Departement Store saat ini sudah berkembang dengan pesat, karena sudah dilengkapi dengan berbagai fasilitas dan kemudahan serta kenyamanan bagi pelanggannya. Bangunan seluas 15.000 meter persegi itu dibuat dengan fasilitas yang lebih lengkap. Selain supermarket dan department store, pihak Chandra juga melengkapi fasilitas lain berupa Hotel, Restoran, arena bermain anak-anak, serta bursa handphone dan komputer.

Manajemen Chandra Departement Store Tanjung Karang telah menggiatkan pelaksanaan komunikasi dalam upayanya untuk meningkatkan disiplin kerja para karyawan. Faktor komunikasi ini perlu mendapatkan perhatian karena mempunyai pengaruh yang cukup besar terhadap terciptanya disiplin kerja karyawan. Salah satu bentuk komunikasi yang dipergunakan Chandra Departement Store Tanjung Karang tertuang dalam bentuk tata tertib karyawan. Hingga tahun 2015, Chandra Departement Store tercatat memiliki 600 orang karyawan tetap.

Tingkat absensi, pemberian surat peringatan serta tingkat perputaran karyawan dapat menunjukan bagaimana tingkat kedisiplinan kerja karyawan pada sebuah perusahaan. Disiplin kerja karyawan apabila komunikasi yang terjadi di dalam perusahaan tercipta hubungan yang harmonis serta dijalankan dengan efektif sehingga tujuan akan semakin mudah 
tercapai. Berdasarkan hal tersebut peneliti tertarik untuk meneliti lebih lanjut dengan judul: "Hubungan Komunikasi Dengan Disiplin Kerja Karyawan Pada Chandra Departement Store Tanjung Karang di Bandar Lampung “.

\section{KAJIAN TEORI}

\section{Pengertian Komunikasi}

Komunikasi merupakan dasar dari setiap usaha antar manusia, karena apabila komunikasi kurang lancer akan menyebabkan kesukaran dalam bekerja sama. Istilah komunikasi memiliki banyak arti, bagi orang awam mungkin akan diartikan sebagai alat atau media pengiriman seperti telepon, telegram atau televisi. Sedangkan orang yang bekerja dalam suatu organisasi istilah komunikasi dapat diartikan sebagai saluran yang menghubungkan antar anggota dalam organisasi, seperti komunikasi formal melalui rantai komando, komunikasi informal, komunikasi verbal dan sebagainya.

Komunikasi adalah proses pemindahan pengertian dalam bentuk gagasan atau informasi dari seseorang ke orang lain. Perpindahan pengertian tersebut melibatkan lebih dari sekedar kata-kata yang digunakan dalam percakapan, tetapi juga ekspresi wajah, intonasi, titk puas vocal dan sebagainya (Handoko, 2003). Sedangkan menurut Niti Semito (1996) yaitu komunikasi adalah jalinan pengertian antara pihak yang satu dengan pihak yang lain, sehingga apa yang dikomunikasikan dapat dimengerti, dipikirkan dan akhirnya dilaksanakan.

\section{Hambatan Dalam Komunikasi}

Menurut Niti Semito (2009) hambatan dalam berkomunikasi tersebut antara lain sebagai berikut : a. Hambatan Psikologis

Hambatan psikologis terjadi karena berbagai hal, misalnya karena komunikasi yang disampaikan sering kali keliru dan diralat, turunnya kewibawaan dari atasan dan sebagainya.

b. Hambatan Kurangnya Motivasi

Kemampuan perusahaan untuk memotivasi para karyawannya merupakan kunci mau tidaknya karyawan untuk melaksanakan semua rencana, instruksi, petunjuk dan saran yang dikomunikasikan.

c. Hambatan Karena Banyaknya Perantara Dalam penyampaiannya, mungkin suatu proses komunikasi harus melalui beberapa perantara. Semakin banyaknya perantara dalam suatu organisasi maka kemungkinan berubahnya isi atau maksud dari pesan yang disampaikan makin besar pula.

\section{d. Hambatan Kurangnya Partisipasi}

Kurangnya partisipasi antara pihak yang satu dengan pihak lain terutama antara pihak atasan dan bawahan merupakan hambatan terhadap komunikasi yang disampaikan. Sebab bila partisipasi kurang, dapat menyebabkan kurangnya rasa tanggungjawab dari penerima komunikasi sehingga kemungkinan komunikasi yang disampaikan tidak akan semuanya dilaksanakan.

\section{Pengertian Disiplin Kerja}

Disiplin kerja karyawan di dalam suatu instansi atau organisasi merupakan salah satu aspek yang sangat penting, karena semakin tinggi tingkat disiplin kerja karyawan, maka akan semakin tinggi pula tingkat produktifitas yang dapat dicapai. Sehingga tujuan perusahaan pun akan semakin mudah tercapai. Pengertian disiplin menurut Alex S. Nitisemito (2009) 
adalah suatu tingkah sikap laku dan perbuatan yang sesuai dengan peraturan dari instansi baik tertulis maupun tidak tertulis.

Kedisiplinan secara sederhana dapat diartikan bilamana karyawan selalu datang dan pulang tepat pada waktunya, menyelesaikan tugas-tugasnya dengan baik dan tepat waktu, mematuhi segala peraturan yang telah ditetapkan organisasi serta norma-norma sosial yang berlaku. Tujuan dari disiplin adalah meningkatkan kesetiaan, ketaatan terhadap tugas yang dibebankan serta untuk menjauhi larangan yang bertentangan dengan disiplin itu sendiri.

Kesadaran terhadap aturan-aturan atau ketentuan-ketentuan yang berlaku di dalam organisasi yang bersangkutan merupakan salah satu faktor penentu tinggi rendahnya tingkat disiplin kerja seseorang. Menjaga kedisiplinan karyawan sangat penting dilakukan dalam usaha menjamin terpeliharanya tata tertib organisasi serta kelancaran pelaksanaan setiap tugas yang diberikan.

Setiap pelanggaran kedisiplinan yang dilakukan oleh para karyawan sebaiknya diberikan semacam sanksi atau hukuman. Hal ini dilakukan agar pelaku kegiatan disipliner merasa jera sehingga tidak akan mengulanginya lagi. Pelanggaran disiplin adalah setiap ucapan, sikap serta perbuatan karyawan yang melanggar ketentuan atau peraturan perusahaan, baik yang dilakukan di dalam maupun diluar jam kerja.

\section{Faktor-faktor yang mempengaruhi Disiplin Kerja}

Untuk dapat meningkatkan disiplin kerja karyawan yang tinggi perlu memperhatikan faktor-faktor yang mempengaruhinya. Adapun faktor-faktor yang dapat meningkatkan disiplin kerja karyawan yang tinggi menurut Nitisemito (2009) adalah: a. Kesejahteraan Karyawan

Untuk meningkatkan disiplin kerja karyawan perlu diimbangi dengan tingkat kesejahteraan yang cukup. Tingkat kesejahteraan yang dimaksud adalah besarnya upah yang diterima sehingga minimal mereka dapat hidup layak. Dengan kelayakan hidup ini mereka akan lebih tenang dalam melaksanakan tuigas-tugasnya, Sehingga diharapkan tingkat disiplin kerja mereka pun semakin meningkat

\section{b. Ancaman}

Untuk menegakkan karyawan perlu adanya ketegasan bagi mereka yang melakukan pelanggaran disiplin. Ancaman yang diberikan kepada karyawan yang akan mendorong karyawan untuk berdisiplin. Ancaman hukuman bertujuan untuk mendidik supaya tingkah laku karyawan sesuai dengan peraturan-peraturan yang ada, bukan bertujuan untuk menghukum.

\section{c. Teladan Pimpinan}

Teladan pimpinan mempunyai pengaruh yang sangat besar dalam menegakan kedisiplinan dalam suatu perusahaan, sebab pimpinan merupakan panutan dan sorotan bagi bawahannya. Dengan teladan yang baik dari pimpinan maka diharapkan para karyawan akan lebih disiplin, bukan hanya sekedar takut akan hukuman, terlebih lagi karena segan atau sungkan kepada pimpinannya.

d. Ketegasan

Ketegasan perlu dilaksanakan untuk menciptakan disiplin kerja. Suatu hukuman yang tidak dilaksanakan dengan benar akan mengakibatkan hal buruk. Membiarkan pelanggaran tanpa adanya tindakan yang tegas sesuai dengan peraturan yang ada akan membuat karyawan menganggap ancaman hanya kosong belaka sehingga 
akan terus melakukan pelanggaran terhadap peraturan yang ada.

e. Tujuan dan kemampuan karyawan Pekerjaan yang dibebankan kepada seorang karyawan harus sesuai dengan kemampuannya, agar karyawan tersebut bekerja dengan sungguh-sungguh dan berdisiplin baik dalam mengerjakan tugasnya.

\section{METODE PENELITIAN}

\section{Objek Penelitian}

Dalam penelitian ini yang menjadi objeknya adalah karyawan Chandra Departement Store Tanjung Karang yang beralamatkan di Jalan Hayam Wuruk No.1 Tanjung Karang. Pelaksanaan penelitian mulai bulan Mei sampai dengan Juli 2016.

\section{Metode dan Teknik Pengumpulan Data}

Metode yang digunakan dalam pengambilan sampel adalah metode nonprobability sampling dengan teknik Purposive Sampling (Judgement Sampling) yaitu sampel yang dipilih dengan cermat sehingga relevan dengan rancangan penelitian.

Dalam penelitian ini jenis data yang diperlakukan adalah :

a. Data Primer

Data primer merupakan data dasar yang akan diperoleh langsung tanpa perantara orang atau lembaga lain sebagai pihak ketiga. Data primer ini diperoleh dengan wawancara melalui responden dengan menggunakan daftar pertanyaan.

b. Data Sekunder

Data skunder merupakan data yang diperoleh melalui orang lain yang berhubungan dengan permasalahan yang dipecahkan. Data sekunder ini diperoleh melalui cara studi dokumenter yaitu mengumpulkan dan mempelajari brosurbrosur serta dokumen organisasi.

\section{Sampel dan Populasi}

Identifikasi populasi yang akan disertakan dalam penelitian ini adalah seluruh karyawan tetap Chandra Departement Store Tanjung Karang yang tercatat resmi bekerja sampai semester II Tahun 2016, yang berjumlah 600 orang. Metode yang digunakan dalam pengambilan sampel adalah metode nonprobability sampling dengan teknik Purposive Sampling (Judgement Sampling) yaitu sampel yang dipilih dengan cermat sehingga relevan dengan rancangan penelitian. maka sampel yang akan diambil sebanyak 86 responden dari karyawan Chandra Departement Store Tanjung Karang.

\section{Metode Analisis Data}

\section{Analisis Kualitatif}

Dilakukan dengan membahas secara kualitatif dari kuesioner yang telah diisi oleh karyawan Chandra Departement Store Tanjung Karang sebagai responden. Analisis ini akan membahas pertanyaan dari kuesioner dengan membuat frekuensi dan persentase berdasarkan hasil tabulasi data responden yang mengisi kuesioner berdasarkan pendekatan manajemen personalia terutama yang terkait dengan komunikasi dan disiplin kerja.

\section{Analisis Kuantitatif}

Dilakukan dengan mengadakan perhitungan-perhitungan secara kuantitatif untuk mengetahui kuat lemahnya korelasi antara komunikasi dengan disiplin kerja karyawan, maka digunakan metode korelasi 
Produck Moment teknik belah dua ganjil genap (Arikunto, 2010), yaitu :

$$
r_{x y}=\frac{n \sum x y-\left(\sum x\right)\left(\sum y\right)}{\sqrt{\left[n \sum x^{2}-\left(\sum x\right)^{2}\right]}\left[n \sum y^{2}-\left(\sum y\right)^{2}\right]}
$$

$r \mathrm{xy}=$ koefisien korelasi $\mathrm{x}$ dan $\mathrm{y}$

$n \quad=$ jumlah sampel yang akan diuji

$x=$ jumlah skor variabel

$y \quad=$ jumlah skor dari seluruh variabel

Kriteria anterpretasi terhadap nilai $\mathrm{r}$ Product Moment adalah :

1. $0,80 \mathrm{~s} / \mathrm{d}$ 1,000 korelasinya dinyatakan: tinggi

2. 0,60 s/d 0,799 korelasinya dinyatakan: cukup

3. 0,40 s/d 0,599 korelasinya dinyatakan: agak rendah

4. 0,20 s/d 0,399 korelasinya dinyatakan: redah

5. 0,00 s/d 0,199 korelasinya dinyatakan: sangat rendah.

Untuk menguji secara hipotesis secara parsial digunakan Uji t dengan rumus :

$$
t_{\text {hitung }}=\frac{r \sqrt{N-2}}{\sqrt{1-r^{2}}}
$$

Keterangan:

$$
\begin{array}{ll}
\mathrm{t}_{\text {hitung }} & =\text { Nilai } \mathrm{t} \\
\mathrm{r} & =\text { Koefisien Korelasi } \\
\mathrm{N} & =\text { Jumlah responden }
\end{array}
$$

Kriteria untuk Uji $\mathrm{t}$ adalah sebagai berikut :

a) Jika $t_{\text {hitung }}>t_{\text {tabel }}$ maka Ha diterima dan Ho ditolak.

b) Jika $t_{\text {hitung }} \leq \mathrm{t}_{\text {tabel }}$ maka Ha ditolak dan Ho diterima.

\section{HASIL DAN PEMBAHASAN}

\section{Uji Validitas dan Uji Reliabilitas Data}

Uji validitas digunakan untuk mengetahui seberapa cermat suatu kuensioner melakukan fungsi ukurnya. Pada penelitian ini uji validitas dilakukan melalui analisis Product - Moment Coefficient of correlation yaitu dengan mengkonsultasikan nilai rhitung yang diperoleh dengan nilai rtable. Jika nilai $r_{\text {hitung }}>r_{\text {table }}$, maka kuesioner yang disebar ke responden dinilai valid.

Setelah melakukan uji validitas, kemudian dilakukan uji reabilitas terhadap butir-butir pernyataan dengan menggunakan koefisien Alpha Croanbach untuk menunjukan stabilitas dan konsistensi alat ukur. Uji reabilitas dalam penelitian ini menggunakan rumus Alpha Croanbach. Nilai Alpha Croanbach yang diperoleh dari variable $\mathrm{X}$ adalah sebesar 0,784 .

\section{Analisis Kuantitatif}

Metode Korelasi Product Moment teknik belah dua ganjil genap digunakan untuk mengetahui kuat lemahnya korelasi antara komunikasi dengan disiplin kerja karyawan. Hasil perhitungan korelasi Product Moment diperoleh angka korelasi $\mathrm{r}$ sebesar 0,812. Hal ini menunjukkan bahwa komunikasi memiliki korelasi yang tinggi terhadap disiplin kerja karyawan, atau dapat dikatakan komunikasi memiliki hubungan yang sangat kuat terhadap peningkatan disiplin kerja karyawan.

Kebenaran hipotesis mengenai hubungan variabel bebas komunikasi dengan variabel terikat disiplin karja diuji dengan menggunakan uji-t dengan tingkat kepercayaan $95 \%$ atau $\alpha=0,05$ dan derajat kebebasan $(\mathrm{dk})=\mathrm{n}-2=86-2=84$. Hasil pengujian menunjukkan bahwa dengan tingkat kepercayaan $95 \%$ dan derajat kebebasan 84 , nilai $t_{\text {hitung }}(12,751)$ adalah 
lebih besar dari nilai $t_{\text {tabel }}(1,989)$. Maka Ho ditolak dan Ha diterima yang berarti secara keseluruhan variabel bebas (komunikasi) mempunyai hubungan yang positif dengan variabel bebas (disiplin kerja).

Pelaksanaan komunikasi yang efektif di dalam perusahaan akan meningkatkan disiplin kerja karyawan. Sebaliknya, kurangnya pelaksanaan komunikasi di dalam sebuah perusahaan akan berakibat pada rendahnya tingkat disiplin kerja karyawan. Secara kualitatif pelaksanaan komunikasi yang telah dilakukan di dalam perusahaan dapat dilihat dari jawaban oleh para responden.

\section{KESIMPULAN DAN SARAN}

\section{Kesimpulan}

Berdasarkan hasil dari analisis data yang diperoleh nilai $r$ sebesar 0,812 dengan nilai $\mathrm{N}=86$. Dengan menggunakan uji-t menunjukkan bahwa dengan tingkat kepercayaan $95 \%$ dan derajat kebebasan (dk) sebesar $84 \quad(86-2=84)$, nilai hitung thitung $(12,751)$ adalah lebih besar dari nilai $t_{\text {tabel }}(1,989)$. Maka Ho ditolak dan Ha diterima yang berarti secara keseluruhan variabel bebas (komunikasi) mempunyai hubungan yang positif dengan variabel bebas (disiplin kerja).

\section{Saran}

Berdasarkan kesimpulan di atas, maka terdapat beberapa saran atau masukan dari penelitian ini yang dapat menjadi pertimbangan bagi manajemen Chandra Departement Store Tanjung Karang sebagai berikut :

1. Lebih memperhatikan dan peduli terhadap factor-faktor yang dapat mempengaruhi disiplin kerja karyawan. Khususnya pada masalah teladan pimpinan untuk selalu berdisiplin dalam bekerja. Pimpinan harus lebih sering untuk memberikan teladan kepada para bawahannya untuk selalu berdisiplin dalam bekerja, sehingga karyawan akan lebih termotivasi lagi untuk berdisiplin dalam bekerja.

2. Kemudahan dalam memperoleh informasi khususnya mengenai prosedur pemberian insentif yang ditetapkan oleh perusahaan perlu ditingkatkan lagi, sehingga karyawandapat dengan mudahmemperoleh informasi yang sudah selayaknya mereka ketahui.

3. Perlu ditingkatkan peran serta karyawan dalam berbagai kegiatan di dalam perusahaan. Seperti kegiatan bermusyawarah untuk mencari jalan keluar dari berbagai permasalahan yang sedang dihadapi perusahaan, sehingga para karyawan akan merasa lebih dihargai.

\section{DAFTAR PUSTAKA}

Arikunto, Suharsimi. 2011. Statistik dan Aplikasi. Jakarta: Penerbit Erlangga.

Bernadian. 2013. Manajemen Personalia. Jakarta: LP3ES.

Dharma. 2011. Manajemen Sumber Daya Manusia. Jakarta: Amara Book.

Gibson, Ivancevich, Donelly, 1999. Organisasi : Perilaku, Struktur, Proses I. (Terjemahan), Nunuk Adiarni. Jakarta: Binarupa Aksara.

Hasibuan, Malayu SP. 2005. Manajemen Sumber Daya Manusia. Edisi Revisi. Jakarta: PT Bumi Aksara.

Nitisemito, Alex S. 2009. Manajemen Personalia. Jakarta: Ghalia Indonesia. 
Rivai. 2001. Manajemen Sumber Daya Manusia. Edisi Revisi. Jakarta: PT Bumi Aksara.

Sedarmayanti, 2007, Manajemen Sumber Daya Manusia. Edisi Revisi. Jakarta: Bumi Aksara.

Sihombing, Umberto. 2005. Organisasi Kepemimpinan Perilaku Administrasi. Jakarta: Bumi Aksara.

Soejono. 2007. Manajemen Organisasi. Jakarta: Bumi Aksara.

Stoner dan Walker, 2008. Pengertian Pengorganisasian. Jakarta: Rineka Cipta.

Sugiyono. 2004. Statistik Untuk Penelitian. Cetakan 4. Bandung: Alfabeta.

Uyanto, S, Stanislaus. 2006. Pedoman Analisis Data dengan SPSS. Edisi Pertama. Cetakan Pertama. Yogyakarta: Graha Ilmu.

Wursanto. 2003. Manajemen Sumber Daya Manusia. Edisi Revisi. Jakarta: PT Bumi Aksara. 